Anadolu Üniversitesi Bilim ve Teknoloji Dergisi A-Uygulamalı Bilimler ve Mühendislik Anadolu University Journal of Science and Technology A- Applied Sciences and Engineering

Cilt: 16 Sayı: 1 - 2015

Sayfa: $15-22$

DOI: $10.18038 /$ btd-a.59620

ARASTIRMA MAKALESİ / RESEARCH ARTICLE

Ebru BİRLİK ÖZKÜTÜK ${ }^{1}$

\title{
SELECTIVE REMOVAL OF Cd(II) USING DOUBLE IMPRINTED POLYMER FROM SYNTHETIC WATER
}

\begin{abstract}
The aim of this study is to prepare ion-imprinted polymers which can be used for the selective removal of $\mathrm{Cd}(\mathrm{II})$ from synthetic water. Ion-imprinted polymer particles have been prepared by molecular imprinting technique using 3-mercaptopropyl-trimethoxysilane as monomer, tetraethoxysilane as crosslinking agent in the presence of $\mathrm{Cd}(\mathrm{II})$ and dodecylamine. After that, the template ions have been removed using $0.1 \mathrm{M} \mathrm{HNO}_{3} /$ ethanol. A batch procedure has been used for the determination of the characteristics of the $\mathrm{Cd}(\mathrm{II})$ solid phase. The obtained results have shown that IIP has a large adsorption capacity $\left(98.2 \mathrm{mgg}^{-1}\right)$. Optimum $\mathrm{pH}$ and adsorption time have found to be 5.0 and $2 \mathrm{~h}$, respectively. In selectivity study, it has found that imprinting have been increased affinity of the material toward $\mathrm{Cd}(\mathrm{II})$ ion over other competitor metal ions with the same charge. The selectivity of $\mathrm{Cd}(\mathrm{II}) / \mathrm{Zn}$ (II), $\mathrm{Cd}(\mathrm{II}) / \mathrm{Cu}$ (II) and $\mathrm{Cd}$ (II)/Hg(II) have found to be $2.73,8.83$ and 112 respectively.
\end{abstract}

Keywords: Ion-imprinted, Cadmium Separation, Preconcentration, Sol-gel

\section{SENTETIKK SUDAN ÇIFT BASKILI POLIMER KULLANILARAK Cd(II)'NIIN SEÇİCI UZAKLAŞTIRILMASI}

\section{$\ddot{O} Z$}

Bu çalışmanın amacı, sentetik sudan Cd(II)'nin seçici uzaklaştırılması için kullanılabilecek iyon baskılı polimer hazırlamaktır. İyon baskılı polimer partikülleri, dodesilamin ve $\mathrm{Cd}(\mathrm{II})$ varlığında, çapraz bağlayıcı olarak teraetoksisilan, monomer olarak 3-merkaptopropil-trimetoksilanın kullanıldığı moleküler baskılama tekniği ile hazırlanmıştır. Daha sonra baskı iyonları 0,1 M HNO3/etanol kullanılarak uzaklaştırılmıştır. Beç işlemi, Cd(II) katı faz özelliklerinin belirlenmesi için kullanılmıştır. Elde edilen sonuçlar, iyon baskılı polimerin büyük adsorpsiyon kapasitesine (98.2 mgg-1) sahip olduğunu göstermiş̧tir. Optimum $\mathrm{pH}$ ve adsorpsiyon süresi sırasıyla 5.0 ve 2 saat olarak bulunmuştur. Seçicilik çalışmalarında, baskılama aynı yüklü diğer yarışmacı metal iyonları üzerinden $\mathrm{Cd}(\mathrm{II})$ iyonlarına doğru materyalin afinitesinin arttığ 1 bulunmuştur. $\mathrm{Cd}(\mathrm{II}) / \mathrm{Zn}(\mathrm{II}), \mathrm{Cd}(\mathrm{II}) / \mathrm{Cu}(\mathrm{II})$ and $\mathrm{Cd}(\mathrm{II}) / \mathrm{Hg}(\mathrm{II})$ 'ın seçicilikleri sırasıyla 2,73; 8,83 ve 112 olarak bulunmuştur.

Anahtar Kelimeler: İyon baskılama, Kadmiyum ayırma, Önderiştirme, Sol jel

\footnotetext{
Eskişehir Osmangazi Üniversitesi, Fen-Edebiyat Fakültesi, Kimya Bölümü, Eskişehir, Türkiye E-mail: ebirlik@ogu.edu.tr Tel and Fax:0 (+90) 2222393578
}

Recieved: 04 July 2015 Revised: 12 May 2015 Revised: 20 May 2015 Accepted: 20 May 2015 


\section{INTRODUCTION}

Cadmium is widely used in several industries including metallurgy, surface treatment, dye synthesis or battery production. Due to its severe toxicity to animals and humans, even at low concentrations, cadmium is known to be one of the most toxic heavy metal elements. Consequently, cadmium removal has been given great priority in the last decade $(\mathrm{Lu}$ and Yan 2004; Lemos and. Baliza, 2005; Fang et al., 2005; Amorim et al., 2005; Davis et al., 2006). Owing to the co-existence of various heavy metal ions in industrial effluents or other water resources, selective removal of toxic metal ions attracts much attention in both industries and researches. Sorption based on suitable sorbent possessing selectivity toward the offending heavy metals, is inherently attractive and more popular for selective removal of metal ion from aquatic environment, especially from dilute aqueous solutions(Lu and Yan 2004; Fang et al., 2005) Therefore, development of novel solid sorbents for selective cadmium clean-up in environmental and biological samples is of great significance.

Molecular imprinting has been defined as a synthetic approach by which a molecular receptor is assembled via template-guided synthesis (Wulff $G, 1995$ ). Binding sites are created by polymerization of the functional and crosslinking monomers in the presence of the target molecule (template) (Ramstrom et al.,1996). Leaching out to the template leaves behind binding sites that are complementary in size and shape to the imprinted molecule. An ion-imprinted polymer is obtained when a metal ion is used as template in the above-described synthesis. In most cases, specific ligands capable to form a stable complex with the metal ion (or metal ion complexes with such specific ligands) are used in the polymerization process. The high selectivity of IIP can be explained by the polymer memory effect toward the metal ion interaction with a specific ligand, coordination geometry, metal ion coordination number, charge and size (Wulff G, 1995). Numerous studies on IIPs and their use for selective preconcentration and separation of metal ions have been reported (Bae et al.,, 1999; Saunders et al.2000; Gladis et al. 2003; Rosatzin et al.1991; Daniel et al., 2005; Daniel et al., 2005; Biju et al., 2003; Prasad et al.;2006; Makote and Dai 2001; Say et al. 2003; Birlik 2006; Ersöz et al., 2004; Liu et al.,2004; Kala et al., 2004; Büyüktiryaki et al.,2005; Andac et al.,2006; Karabork et al.,2008; et al., 2005).
In this study, an ion-imprinting polymer was prepared preorganizing 3-mercaptopropyltrimethoxysilane monomer, dodecylamine (DDA) and cadmium (template) ion with the goal of preparing a solid-phase which has the high selectivity for $\mathrm{Cd}(\mathrm{II})$ ions. Ion-imprinted beads were polymerized with the use of 3mercaptopropyl-trimethoxysilane-Cd(II)-DDA complex monomer and tetraethoxysilane (TEOS). After removal of $\mathrm{Cd}(\mathrm{II})$ ions, ionimprinted beads were used for solid-phase extraction and preconcentration of $\mathrm{Cd}(\mathrm{II})$ ions.

Cd(II) adsorption and selectivity studies of $\mathrm{Cd}$ (II) versus other metal ions such as $\mathrm{Hg}$ (II), $\mathrm{Cu}(\mathrm{II})$ and $\mathrm{Zn}(\mathrm{II})$, were reported here. Finally, use of $\mathrm{Cd}(\mathrm{II})$ receptor beads for the separation and preconcentration of $\mathrm{Cd}(\mathrm{II})$ was also discussed.

\section{EXPERIMENTAL}

\subsection{Chemicals}

DDA (dodecylamine) and 3mercaptopropyl-trimethoxysilane were supplied from Aldrich Chemical (USA). All other chemicals were analytical reagent grade and purchased from Merck (Darmstadt,Germany).

\subsection{Apparatus}

A Hitachi $180-70$ polarized Zeeman flame atomic absorption spectrophotometer (FAAS) with deuterium background correction was used for the determination of $\mathrm{Cd}(\mathrm{II}), \mathrm{Hg}(\mathrm{II})$ and $\mathrm{Zn}$ (II) ions. FTIR was used in the range of 4000$400 \mathrm{~cm}^{-1}$ to investigate the double-imprinted polymer (FTIR 100 series, Perkin Elmer, USA). Jenway $3100 \mathrm{pH}$-meter was used to mesaure $\mathrm{pH}$ values.

\subsection{Preparation of Ion-Imprinted Polymers}

5.561 g DDA was dissolved in 44.7/57.5 $\mathrm{mL}$ of methanol/ water mixture and $4.626 \mathrm{~g}$ $\mathrm{Cd}\left(\mathrm{NO}_{3}\right) \cdot \mathrm{H}_{2} \mathrm{O}$ was added into this solution with continuous stirring at room temperature. Then, this mixture was reacted with $3.5 \mathrm{~mL}$ of $3-$ mercaptopropyl-trimethoxysilane for $4 \mathrm{~h}$. The obtained mixture was crosslinked by $3.5 \mathrm{~mL}$ of tetraethoxysilane (TEOS) under refluxing conditions in an oil bath (ca. $110{ }^{\circ} \mathrm{C}$ ) for $8 \mathrm{~h}$. The solid product was recovered by filtration. Then, it was refluxed in ethanol/ $/ \mathrm{HNO}_{3}$ to extract the surfactant templates with ethanol and to strip 
the $\mathrm{Cd}(\mathrm{II})$ ion templates by protonation of $0.1 \mathrm{M}$ $\mathrm{HNO}_{3}$. The product was washed with deionize water, and dried under vacuum. For comparison of single and double imprinted polymer, the ionimprinted polymer was also prepared using an identical procedure, but without the addition of
DDA. The non-imprinted polymer (NIP) was prepared in paralel without addition of $\mathrm{Cd}(\mathrm{II})$. The scheme 1 shows the synthesis of ionimprinted polymer using $\mathrm{Cd}(\mathrm{II})$ and DDA.
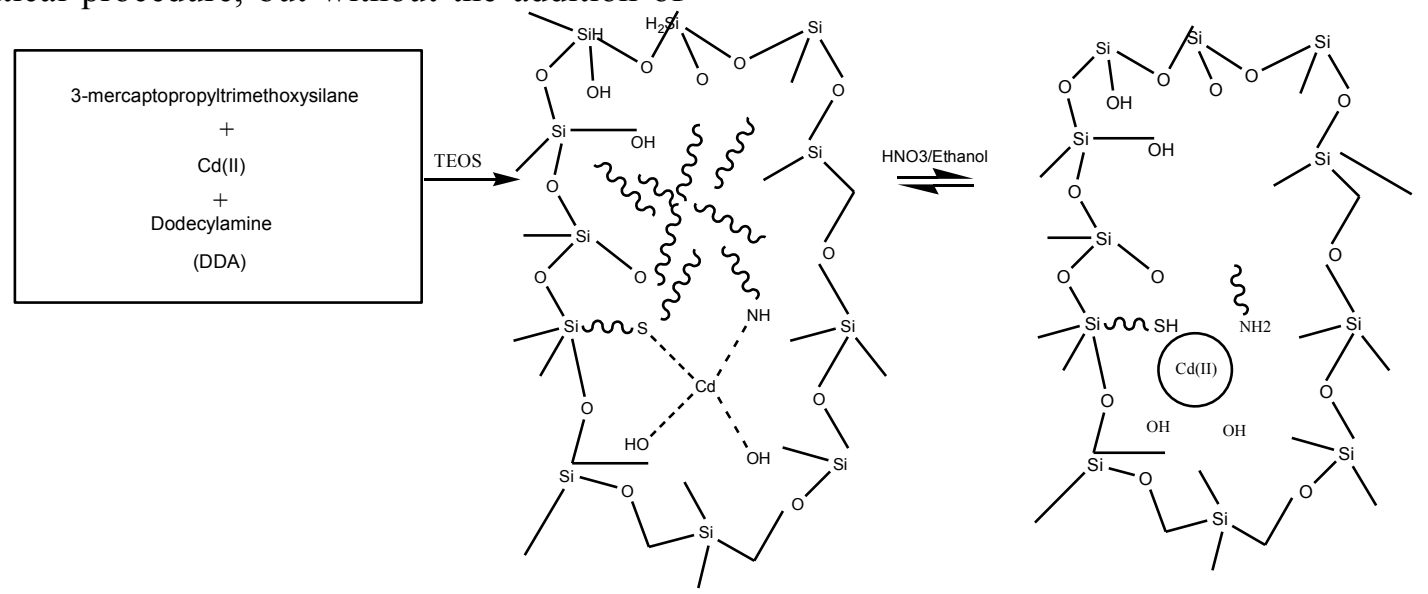

Scheme 1. The schematic representation of ion-imprinted polymer using Cd(II) and DDA.

\subsection{Sorption Experiments}

The effect of $\mathrm{pH}$ on the sorption of $\mathrm{Cd}(\mathrm{II})$ was tested by equilibrating $25 \mathrm{mg}$ prepared sorbent with $25 \mathrm{ppm}, 25 \mathrm{~mL}$ of Cd(II) solutions under different $\mathrm{pH}$ conditions. The $\mathrm{pH}$ of the solutions was adjusted using $\mathrm{NaOH} / \mathrm{HNO}_{3}$ solution. Samples were regularly collected at appropriate time intervals, separated and analyzed for $\mathrm{Cd}$ (II) content. To measure the sorption capacity, $25 \mathrm{mg}$ ion-imprinted sorbent was equilibrated with $25 \mathrm{~mL}$ of various concentrations of $\mathrm{Cd}(\mathrm{II})$ solutions at $\mathrm{pH} 5.0$.

Competitive loading of $\mathrm{Cd}(\mathrm{II}), \mathrm{Hg}(\mathrm{II})$ and $\mathrm{Zn}(\mathrm{II})$ by IIP and NIP sorbents was investigated in $\mathrm{Cd}(\mathrm{II}) / \mathrm{Zn}(\mathrm{II})$ and $\mathrm{Cd}(\mathrm{II}) / \mathrm{Hg}(\mathrm{II})$ binary aqueous solutions at $\mathrm{pH} 5.0 .25 \mathrm{mg}$ portion of IIP and NIP sorbent was treated with $10 \mathrm{ppm}, 25$ $\mathrm{mL}$ of $\mathrm{Cd}(\mathrm{II}) / \mathrm{Zn}$ (II), $\mathrm{Cd}(\mathrm{II}) / \mathrm{Hg}$ (II) mixtures. In all the above batch experiments, the mixtures were centrifugally separated. The cadmium concentration in the sorbent was determined by FAAS. The amount of adsorbed $\mathrm{Cd}(\mathrm{II})$ was calculated by the following Eq. (1):

$\mathrm{Q}=\left(\mathrm{C}_{0}-\mathrm{C}_{\mathrm{e}}\right) \mathrm{V} / \mathrm{m}$

(1)

Where $\mathrm{C}_{0}$ and $\mathrm{C}_{\mathrm{e}}$ represent initial and equilibration concentration of $\mathrm{Cd}(\mathrm{II})$, respectively, $\mathrm{V}$ is the volume of solution, $\mathrm{m}$ is the weight of the sorbent.

For the preconcentration of $\mathrm{Cd}(\mathrm{II})$ ions, 100
$\mathrm{mL}$ of the aqueous solution containing $5.0 \mathrm{ng}$ $\mathrm{mL}^{-1} \mathrm{Cd}(\mathrm{II})$ was treated with $25 \mathrm{mg}$ imprinted microbeads at $\mathrm{pH} 5.0$ for $2 \mathrm{~h}$. Finally, IIPs were separated from the adsorption media by filtration and $10 \mathrm{~mL}$ of $\mathrm{HNO}_{3}$ solution was added and stirred at $400 \mathrm{rpm}$ for $3 \mathrm{~h}$. Imprinted polymers were separated from the desorption media and the concentration of $\mathrm{Cd}$ (II) ions in the desorption media was determined by FAAS system.

\subsection{Reusability of the Ion-imprinted Sorbent}

The $\mathrm{Cd}(\mathrm{II})$ ion recognized on the sorbent was stripped washing with $0.1 \mathrm{M} \mathrm{HNO}_{3}$. The acid-treated sorbent was rinsed several times with deionized water. The same sorbent was extracted and regenerated five times and then used to remove $\mathrm{Cd}(\mathrm{II})$ ion.

\section{RESULTS and DISCUSSION}

\subsection{Characterization of IIP}

The resulting imprinted particles were characterized by FTIR. The FTIR spectra of the ion-imprinted polymer showed aliphatic $\mathrm{C}-\mathrm{H}$ band at $2926 \mathrm{~cm}^{-1}$, Si-O-Si band at $1047 \mathrm{~cm}^{-1}$, S$\mathrm{H}$ band at 956 and $799 \mathrm{~cm}^{-1}$. This result indicated that DDA-Cd(II) was connected to 3mercaptopropyl-trimethoxysilane. 


\subsection{Cd(II) Sorption to The Sorbent}

\subsubsection{Equilibrium Adsorption Time}

For the determination of adsorption time, 25 $\mathrm{mg}$ sorbent was added to $25 \mathrm{~mL} 25 \mathrm{mgL}^{-1}$ of $\mathrm{Cd}(\mathrm{II})$ solution at $\mathrm{pH}$ 5.0. The resulting suspension was stirred for different periods of time in the range of 15 to $180 \mathrm{~min}$., using magnetic stirrer. After the adsorption of $\mathrm{Cd}(\mathrm{II})$ ion by the imprinted polymer, the amount of $\mathrm{Cd}(\mathrm{II})$ ion in the solution was determined by FAAS.

Figure 1 shows adsorption rates of $\mathrm{Cd}(\mathrm{II})$ ions onto the ion-imprinted polymers from aqueous solutions. Note that the ordinate values on this were calculated by using the expression given eq. (1). As seen here, adsorption equilibrium was gradually reached within $2 \mathrm{~h}$ for ion-imprinted polymers.

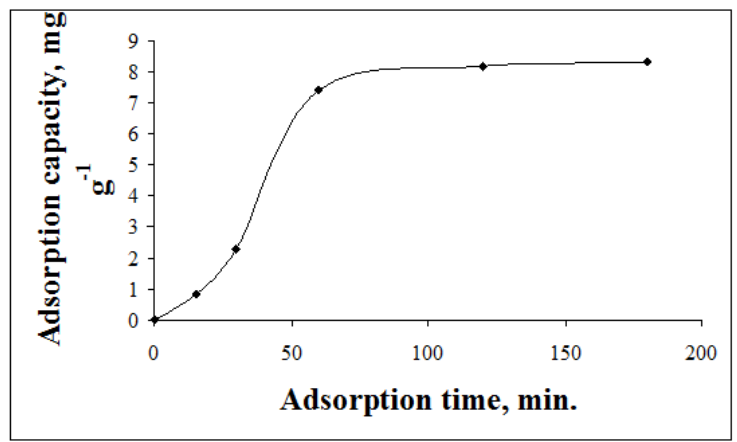

Figure 1. Adsorption rates of $\mathrm{Cd}(\mathrm{II})$ ions on the ion-imprinted polymers; $\mathrm{pH}$ : $5.0 ; \mathrm{T}: 25{ }^{\circ} \mathrm{C}$.

Several experimental data on the adsorption of various ions by chitosan have shown a wide range of adsorption rates. For example, Li et al. have prepared ion-imprinted sorbent for selective separation of $\mathrm{Cd}(\mathrm{II})$ from aqueous solution and beads and reported $20 \mathrm{~min}$. equilibrium adsorption time ( $\mathrm{Li}$ et al., 2007). Andaç et al. have used Cd(II)-imprinted polymer for cadmium removal from human plasma and found $60 \mathrm{~min}$. as an equilibrium time (Andaç et al., 2004). These results can be explained that, the interaction between the binding sites which are produced by double-imprinted technique and Cd(II) ions needs more time to reach equilibrium than that of single imprinted technique.

\subsubsection{Effect of pH}

The effect of $\mathrm{pH}$ on $\mathrm{Cd}(\mathrm{II})$ sorption onto ion-imprinted composite sorbent was investigated varying the $\mathrm{pH}$ between 2.0 and 7.0, as shown in Figure 2. The sorption of $\mathrm{Cd}(\mathrm{II})$ increased as the $\mathrm{pH}$ increased. This mainly due to the protonation of the thiol moiety, which diminished the ability of thiol grup to be involved in chelate formation with the $\mathrm{Cd}(\mathrm{II})$ in aqueous solution at $\mathrm{pH} \leq 3$. The $\mathrm{pH} 5.0$ was chosen for further sorption performance, because in this $\mathrm{pH}$, neither precipitation of the metal hydroxide nor the protonation of thiol with the active chelating group was observed.

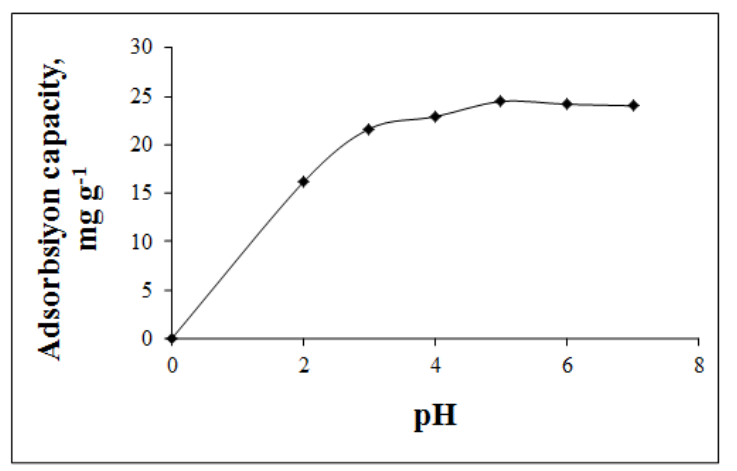

Figure 2. Effect of $\mathrm{pH}$ on sorption of $\mathrm{Cd}(\mathrm{II})$ ions on ion-imprinted polymers $\left(\mathrm{T}: 25{ }^{\circ} \mathrm{C}\right.$.

\subsubsection{Adsorption Capacity}

The adsorption capacity of $\mathrm{Cd}(\mathrm{II})$ sorption to the ion-imprinted composite sorbent was also investigated. Figure 3 shows effects of initial concentration of $\mathrm{Cd}(\mathrm{II})$ ions onto the adsorption capacity of the ion-imprinted polymer at $\mathrm{pH}$ 5.0. The amount of $\mathrm{Cd}(\mathrm{II})$ ions adsorbed per unit mass of the polymer (i.e., adsorption capacity) increased with the initial concentration of $\mathrm{Cu}$ (II) ions. The maximum adsorption (corresponding a $500 \mathrm{ppm} \mathrm{Cu}(\mathrm{II})$ ion initial concentration), which represents saturation of active points (which are available for $\mathrm{Cd}(\mathrm{II})$ ions) on the polymers was $98.2 \mathrm{mg} \mathrm{Cd}(\mathrm{II}) / \mathrm{g}$ polymer. 


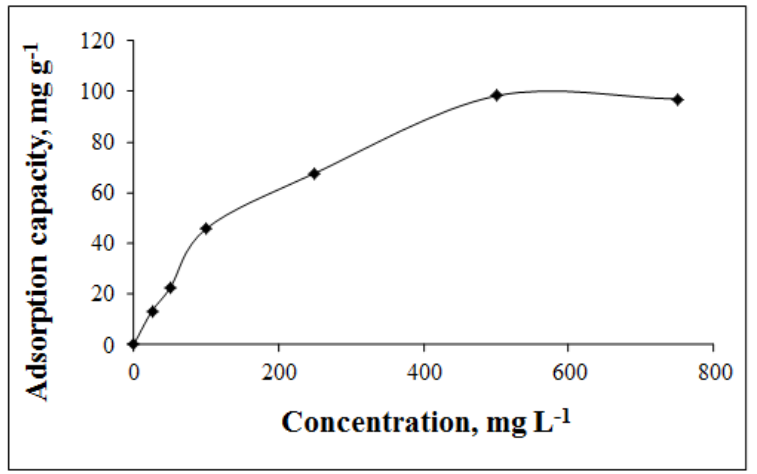

Figure 3. Adsorption capacity of $\mathrm{Cd}(\mathrm{II})$ ions on the ion-imprinted polymer; $\mathrm{pH}: 5.0 ; \mathrm{T}: 25^{\circ} \mathrm{C}$.

During batch experiments, adsorption isotherms were used to evaluate adsorption properties. For the systems considered, the Langmuir model was found to be applicable in interpreting $\mathrm{Cd}(\mathrm{II})$ adsorption by imprinted polymer. Figure 4 shows the dependence of the equilibrium concentration on the adsorbed amonut of $\mathrm{Cd}(\mathrm{II})$ onto the double-imprinted polymer. Langmuir adsorption model assumes that the molecules are adsorbed at a fixed number

of well-defined sites, each of which can only hold one molecule. These sites are also assumed to be energetically equivalent, and distant to each other so that there are no interactions between molecules adsorbed to adjacent sites (Labrou et al., 1995). The corresponding transformations of the equilibrium data for $\mathrm{Cd}(\mathrm{II})$ ions gave rise to a linear plot, indicating that the Langmuir model can be applied in these systems and describes by the equation:

$$
\mathrm{Q}=\mathrm{Q}_{\max } \mathrm{bC}_{\mathrm{e}} /\left(1+\mathrm{bC}_{\mathrm{e}}\right)
$$

where $\mathrm{Q}$ is the concentration of bound $\mathrm{Cd}$ (II) ions in the adsorbent $\left(\mu \mathrm{molg}^{-1}\right), \mathrm{C}_{\mathrm{e}}$ is the equilibrium $\mathrm{Cd}(\mathrm{II})$ ions concentration in solution $\left(\mu \mathrm{molL}^{-1}\right), \mathrm{b}$ is the Langmuir constant $\left({\left.\mathrm{g} \mu \mathrm{mol}^{-1}\right)}^{-1}\right.$ and $\mathrm{Q}_{\max }$ is the maximum adsortion capacity $\left(\mu \mathrm{molg}^{-1}\right)$.

The maximum adsorption capacity $\left(\mathrm{Q}_{\max }\right)$ data for the adsorption of $\mathrm{Cd}(\mathrm{II})$ ions was obtained from the experimental data. The correlation coefficient $\left(\mathrm{R}^{2}\right)$ was found to be 0.9713 . The Langmuir adsorption model can be applied in this affinity adsorbent system. It should be also noted that maximum adsorption capacity $\left(\mathrm{Q}_{\max }\right)$ was found to be $101.8 \mathrm{mgg}^{-1}$.

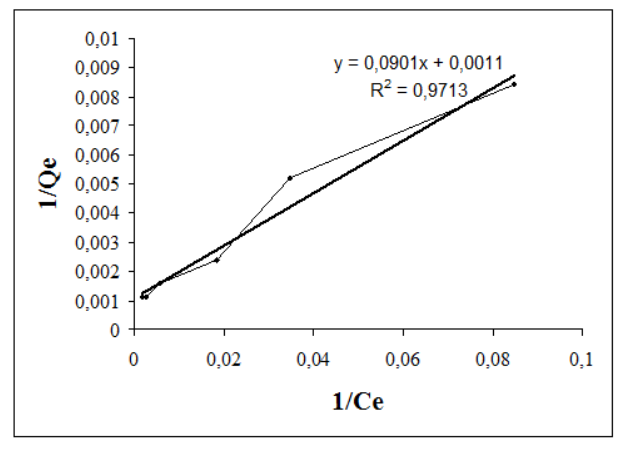

Figure 4. Adsorption isotherm of $\mathrm{Cd}(\mathrm{II})$ ionimprinted polymer; $\mathrm{pH}: 5.0 ; \mathrm{T}: 25^{\circ} \mathrm{C}$.

\subsubsection{Selectivity Studies}

The selectivity of the IIP and NIP sorbents was investigated by studying competitive loading of $\mathrm{Hg}(\mathrm{II}), \mathrm{Cu}(\mathrm{II})$ and $\mathrm{Zn}$ (II) in their binary mixture. Table 1 summarized parameters of distribution coefficient $\left(\mathrm{K}_{\mathrm{d}}\right)$, selectivity coefficient (k) of the sorbent toward $\mathrm{Cd}(\mathrm{II})$, and the relative selectivity coefficient (k'). The $\mathrm{k}$ value for the imprinted sorbent showed significant increase compared with that of the non-imprinted sorbent.

A comparison of the selectivity coefficient of IIP to the selectivity coefficient of NIP showed that the imprinted matrix for $\mathrm{Cd}(\mathrm{II}) / \mathrm{Zn}(\mathrm{II}), \mathrm{Cd}(\mathrm{II}) / \mathrm{Cu}(\mathrm{II})$ and $\mathrm{Cd}(\mathrm{II}) / \mathrm{Hg}$ (II) were $2.73 ; 8.83$ and 112.8 times greater than non-imprinted matrix, respectively (Table 1 ). This means that $\mathrm{Cd}(\mathrm{II})$ ions can be determined even the presence of $\mathrm{Zn}(\mathrm{II}), \mathrm{Cu}(\mathrm{II})$ and $\mathrm{Hg}$ (II) interferents.

\subsubsection{Reusability of The Sorbent}

The reusability of sorbent is very important for economic competition. Adsorbed $\mathrm{Cd}(\mathrm{II})$ ions were removed by the addition of $0.1 \mathrm{M} \mathrm{HNO}_{3}$ (Afterwards, the sorption ability was resumed). In order to test the reusability, the adsorption/desorption cycle was repeated 7 times (Figure 5).

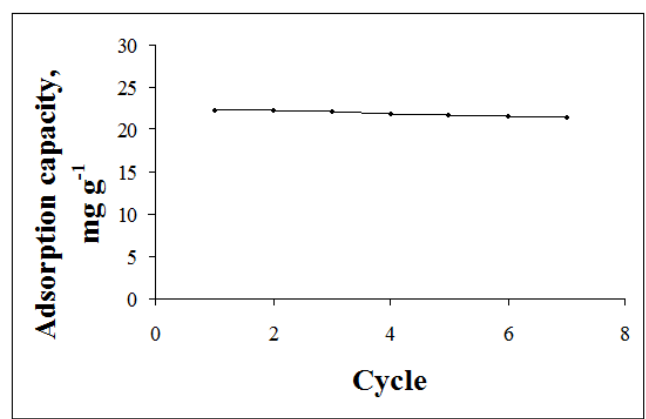

Figure 5. Adsorption-desorption cycle 
The results showed that the adsorption capacity of the recycled double imprinted particles can still be maintained at $95 \%$ of its original value at the $7^{\text {th }}$ cycle.

\subsubsection{Analytical Performance}

For the preconcentration of cadmium ions, $100 \mathrm{~mL}$ of the aqueous solution containing 5.0 $\mathrm{ng} \mathrm{mL} \mathrm{m}^{-1} \mathrm{Cd}$ (II) ions was treated with $25 \mathrm{mg}$ ionimprinted microbeads at $\mathrm{pH} 5.0$ for $2 \mathrm{~h}$. Finally, polymeric microbeads were separated from the adsorption media and $10 \mathrm{~mL}$ of $\mathrm{HNO}_{3}$ solution was added and stirred at $400 \mathrm{rpm}$ for $2 \mathrm{~h}$. Imprinted microbeads were removed from the desorption medium and concentration of $\mathrm{Cd}$ (II) ions in the desorption medium was determined by FAAS.

The characteristic performance data for the off-line preconcentration procedure were given in Table 2

Table 1. The effect of imprinting on selectivity

\begin{tabular}{|c|c|c|c|c|c|c|}
\hline Polymer & $\begin{array}{l}\mathrm{Cd}(\mathrm{II}) \\
\left(\mathrm{mgL}^{-1}\right)\end{array}$ & $\begin{array}{l}\mathrm{Zn}(\mathrm{II}) \\
\left(\mathrm{mgL}^{-1}\right)\end{array}$ & $\begin{array}{l}\mathbf{K}_{\mathrm{D}} \\
(\mathbf{C d}(\mathrm{II}))\end{array}$ & $\begin{array}{l}K_{\mathrm{D}} \\
(\mathrm{Zn}(\mathrm{II}))\end{array}$ & $\mathbf{k}$ & $\mathbf{k}^{\prime}$ \\
\hline Non-Mip & 10 & 10 & 10160 & 23750 & 0.428 & \\
\hline Ion-Imprinted Polymer & 10 & 10 & 48260 & 41190 & 1.171 & 2.73 \\
\hline Non-Mip(without DDA) & 10 & 10 & 5934 & 6013 & 0.983 & \\
\hline $\begin{array}{l}\text { Ion-Imprinted } \\
\text { (without DDA) }\end{array}$ & 10 & 10 & 2626 & 2588 & 1.01 & 1.028 \\
\hline Polymer & $\begin{array}{l}\text { Cd(II) } \\
\text { (mg/l) }\end{array}$ & $\begin{array}{l}\mathrm{Hg}(\mathrm{II}) \\
(\mathrm{mg} / \mathrm{l})\end{array}$ & $\begin{array}{l}\mathbf{K}_{\mathbf{D}} \\
(\mathbf{C d}(\mathrm{II}))\end{array}$ & $\begin{array}{l}\mathbf{K}_{\mathrm{D}} \\
(\mathbf{H g}(\mathrm{II})\end{array}$ & $\mathbf{k}$ & $\mathbf{k}^{\prime}$ \\
\hline Non-Mip & 10 & 10 & 1799 & 162900 & 0.011 & \\
\hline Ion-Imprinted polymer & 10 & 10 & 34840 & 28240 & 1.243 & 112 \\
\hline Non-Mip(without DDA) & 10 & 10 & 6257 & 162900 & 0.038 & \\
\hline $\begin{array}{l}\text { Ion-Imprinted } \\
\text { (without DDA) }\end{array}$ & 10 & 10 & 4970 & 162900 & 0.03 & 0.78 \\
\hline Polymer & $\begin{array}{l}\mathrm{Cd}(\mathrm{II}) \\
(\mathrm{mg} / \mathrm{l})\end{array}$ & $\begin{array}{l}\mathrm{Cu}(\mathrm{II}) \\
(\mathrm{mg} / \mathrm{l})\end{array}$ & $\begin{array}{l}\mathbf{K}_{\mathrm{D}} \\
(\mathbf{C d}(\mathrm{II}))\end{array}$ & $\begin{array}{l}\mathbf{K}_{\mathbf{D}} \\
(\mathbf{C u}(\mathrm{II})\end{array}$ & $\mathbf{k}$ & $\mathbf{k}^{\prime}$ \\
\hline Non-Mip & 10 & 10 & 5689 & 62290 & 0.091 & \\
\hline Ion-Imprinted polymer & 10 & 10 & 35900 & 44670 & 0.8 & 8.83 \\
\hline Non-Mip(without DDA) & 10 & 10 & 3468 & 6496 & 0.53 & \\
\hline $\begin{array}{l}\text { Ion-Imprinted } \\
\text { (without DDA) }\end{array}$ & 10 & 10 & 2717 & 4394 & 0.618 & 1.15 \\
\hline
\end{tabular}

Table 2. Performance characteristics of the preconcentration procedure

\begin{tabular}{ll}
\hline Parametreler & Cd \\
\hline Precision (R.S.D) & $7.9 \%$ \\
Detection limit (3s) & $0.04 \mathrm{ng} / \mathrm{mL}$ \\
Linear calibration range & $0.01-15.0 \mathrm{ng} / \mathrm{mL}$ \\
$\begin{array}{l}\text { Regression equation } \\
\text { (after preconcentration) }\end{array}$ & $\mathrm{AA}=0.0034 \mathrm{Cd}+0,0013$ \\
$\begin{array}{l}\text { Conventional regression equation } \\
\text { Enrichment factor }\end{array}$ & $\mathrm{AA}=0.0131 \mathrm{Cd}+0.0472$ \\
& $(0.0034 \mathrm{ng} / \mathrm{mLx} 1000 \mu \mathrm{g} / \mathrm{mL} / 0.0131=259$
\end{tabular}

The precision of method for a standard, evaluated as the relative standard deviation (R.S.D:, $n=7$ ) 
was $7.9 \mathrm{ngmL}^{-1} \mathrm{Cd}(\mathrm{II})$ ions. The detection and determination limits, defined as the concentration of analyte giving signals equivalent to three the standart deviation of the blank plus the net blank intensity for $100 \mathrm{~mL}$ of sample volume, were $0.04 \mathrm{ngmL}^{-1}$. The preconcentration procedure showed a linear curve within the concentration range from 0.01 to $15 \mathrm{ngmL}^{-1}$. The enrichment factor, defined as the ratio of the slopes of linear section of the calibration graphs before and after the preconcentration, was 259 .

Xie et al. (Xie et al., 2008) have studied solid phase extraction of $\mathrm{Cd}(\mathrm{II})$ using gallic acidmodified silica gel and reported detection limit as $0.65 \mu \mathrm{g} \mathrm{L}^{-1}$. Prasad et al. (Prasad et al,2006) have investigated preconcentration of cadmium and lead from soils onto 5,7-dibromoquinoline-8-ol embedded benzophenone and found the detection limit as $0.1 \mu \mathrm{gL}^{-1}$.

\section{CONCLUSIONS}

IIP materials have attracted much attention in recent past as a highly selective polymeric sorbent material with microenvironment around the metal centre. Of late, IIPs have come to reckoning for selective removal of inorganics as this technique provides higher enrichment factors and selectivity coefficients compared to NIP. As shown in this study, IIPs can be successfully used as selective sorbents to clean up. In this study, IIP was prepared to preorganize 3-mercaptopropyl-trimethoxysilane monomer and cadmium ion and DDA with the goal preparing a solidphase which has the high selectivity for Cd(II) ions. The amount of adsorbed Cd(II) ions per unit mass of the polymer increased with the initial concentration of the $\mathrm{Cd}(\mathrm{II})$ ions. The maximum adsorption capacity of IIP was 98.2 mgg-1 The adsorption was fast and the time required to reach equilibrium conditions was about $2 \mathrm{~h}$ for IIP and seems to be very satisfactory.

\section{REFERENCES}

Amorim, F. A. C., Ferreira, S. L. C., (2005) Determination of cadmium and lead in table salt by sequential multi-element flame atomic absorption spectrometry. Talanta, 65, 960964

Andac, M., Say, R., A. Denizli, (2004). Molecular recognition based cadmium removal from human plasma Journal of Chromatography B., 811, 119-126.

Andac, M., Ozyapi, E., Senel, S., Say, R., A.Denizli, (2006). Ion-Selective Imprinted Beads for Aluminum Removal from Aqueous Solutions Industrial \& Engineering Chemistry Research., 45(5), 1780-1786.

Araki, K., Maruyama, T., Kamiya, N., Goto M., (2005) Metal ion-selective membrane prepared by surface molecular imprinting.J. Chromatography B., 818, 141-145.
This adsorption equilibrium is most probably due to high complexation and geometric shape affinity (or between $\mathrm{Cd}(\mathrm{II})$ ions and $\mathrm{Cd}(\mathrm{II})$ ion cavities. The relative selectivity coefficient is an indicator to express an adsorption affinity of recognition sites to imprinted $\mathrm{Cd}(\mathrm{II})$ ions. The results showed that non-imprinted beads for $\mathrm{Cd}(\mathrm{II}) / \mathrm{Zn}(\mathrm{II})$, $\mathrm{Cd}(\mathrm{II}) / \mathrm{Cu}(\mathrm{II})$ and $\mathrm{Cd}(\mathrm{II}) / \mathrm{Hg}(\mathrm{II})$ were $2.73 ; 8.83$ and 112.8 times greater than non-imprinted matrix, respectively, for ion-imprinted polymer. Ionimprinted polymer was exhibited in most of the work to increase metal loading capacities and selectivity, as compared to ion-imprinted sorbent (without DDA). This succesful preparation of ion-imprinted polymer using metal ion and surfactant (DDA) templates demonstrated the feasibility of direct formation of the imprinted mesoporous sorbent with functional ligands for $\mathrm{Cd}(\mathrm{II})$ ion.

Bae, S. Y., Southard G. L., Murray, G. M., (1999). Molecularly imprinted ion exchange resin for purification preconcentration and determination of $\mathrm{UO} 22+$ by spectrophotometry and plasma spectrometry Analytica Chimica Acta 397 (1-3), 173-181.

Biju, V. M., Gladis, J. M., Rao T. P., (2003) Ion imprinted polymer particles: synthesis, characterization and dysprosium ion uptake properties suitable for analytical applications Analytica Chimica Acta 478, 43-51.

Birlik, E., Ersöz A., Denizli A., Say, R., (2006). Preconcentration of Copper usind DoubleImprinted Polymer via Solid Phase Extraction Analytica Chimica Acta 565, 145-151. 
Büyüktiryaki, S., Say, R., Ersöz, A., Birlik, E., Denizli, A., (2005). Selective preconcentration of thorium in the presence of $\mathrm{UO}_{2}{ }^{2+}, \mathrm{Ce}^{3+}$ and $\mathrm{La}^{3+}$ using Th(IV)-imprinted polymer, Talanta., 67 640-645.

Daniel, S., Babu, P. E. J., Rao, T. P., (2005) Preconcentrative Separation of Palladium(II) Using ... of Binding Parameters Based on Adsorption Isotherm Models, Talanta, 65(2): 441-452.

Davis, A. C., Wu, P., Zhang, X. F., Hou, X. D., Jones B. T., (2006). Determination of cadmium in biological samples, Applied Spectroscopy Reviews

41, 35-75.

Ersöz, A., Say, R., Denizli A., (2004). Nickel(II) IonImprinted Solid Phase Extraction and Preconcentration In Aqueous Solutions in Packed-Bed Columns, Analytica Chimica Acta, 502, 91-97

Fang, G. Z., Tan, J., Yan X. P., (2005). An ionimprinted functionalized silica gel sorbent prepared by a surface imprinting techniquecombined with a sol-gel process for selective solid-phaseextraction of cadmium(II). Analytical Chemistry 77:17341739

Gladis, J. M., Rao, T. P., (2003) Synthesis and analytical applications of uranyl ion imprinted polymer particles, Analytical Letters, 36, 2107-2121.

Kala, R., Gladis, J. M., Rao, T. P., (2004). Preconcentrative separation of erbium from $\mathrm{Y}$, Dy, Ho, Tb and Tm by using ion imprinted polymer particles viasolid phase extraction . Analytica Chimica Acta, 518: 143-150.

Karabork, M., Ersoz, A., Denizli, A., Say, R., (2008). Polymer-Clay Nanocomposite Iron Traps Based on Intersurface Ion-Imprinting Industrial \& Engineering Chemistry Research, 47, 2258-2264 .

Labrou, N. E., Karagouni, A., Clonis, Y. D., (1995). Biomimetic-dye affinity adsorbents for enzyme purification: application to the onestep purification of Candida boidinii formate dehydrogenase, Biotechnology and Bioengineering 48, 278-288.
Lemos, V. A., Baliza, P. X., (2005). Amberlite XAD2 functionalized with 2 -aminothiophenol as a new sorbent for on-line preconcentration of cadmium and copper Talanta, 67, 564-570.

Li, F., Jiang, H., Zhang, S., (2007). An ion-imprinted silica-supported organic-inorganic hybrid sorbent prepared by a surface imprinting technique combined with a polysaccharide incorporated sol-gel process for selective separation of cadmium(II) from aqueous solution Talanta, 71, 1481-1493.

Liu, Y., Chang, X., Wang, S., Guo, Y., Din, B., Meng, S., (2005). Highly selective determination of inorganic mercury(II) after preconcentration with $\mathrm{Hg}(\mathrm{II})$-imprinted diazoaminobenzene-vinylpyridine copolymers.

Analytica Chimica Acta, 538 (1-2) 85-91.

Lu, Y. K., Yan, X. P., (2004). An imprinted organicinorganic hybrid sorbent for selective separation of cadmium from aqueous solution Analytical Chemistry, 76, 453-457.

Makote, R. D., Dai, S., (2001). Matrix-induced modification of imprinting effect for $\mathrm{Cu} 2+$ adsorption in hybrid silica matrices Analytica Chimica Acta, 435, 169-176.

Prasad, K., Kala, R., Rao, T. P., Naidu, G. R. K., (2006). Ion imprinted polymer based ionselective electrode for the trace determination of dysprosium(III) ions Analytica Chimica Acta, 566, 69-74

Prasad, K., Gopikrishna, P., Kala, R., Rao, T. P., Naidu, G. R. K., (2006). Solid phase extraction vis-à-vis coprecipitation preconcentration of cadmium and lead from soils onto 5,7-dibromoquinoline-8-ol embedded benzophenone and determination by FAAS, Talanta., 69, 938-945.

Ramstrom, O., Ye, L., Mosbach, K., (1996). Artificial antibodies to corticosteroids prepared by molecular imprinting, Chemistry and Biology, 3, 471-477.

Rosatzin, T., Andersson, L. I., Simon, W., Mosbach K., (1991). Preparation of $\mathrm{Ca} 2+$ selective sorbents by molecular imprinting using polymerizable ionophores, Journal of the 
Chemical Society, Perkin Transactions 2, 1261-1265.

Saunders, G. D., Foxon, S. P., Walton, P. H., Joyce M. J., Port S. N., (2000). A selective uranium extraction agent prepared by polymer imprinting. Chemical Communications, 273274

Say, R., Birlik, E., Ersöz, A., Yilmaz, F., Gedikbey, T., Denizli, A., (2003). Preconcentration of copper on ion-selective imprinted polymer microbeads, Analytica Chimica Acta, 480, 251-258.

Vigneau, O., Pinel, C., Lemaire, M., (2002). "Solidliquid separation of lanthanide/lanthanide and lanthanide/actinide using ionic imprinted polymer based on a DTPA derivativeChemistry Letters, 202-203.

Wulff, G. (1995). Molecular imprinting in crosslinked materials with the aid of molecular templates - a way towards artificial antibodiesAngewandte Chemie International Edition 34 (17), 1812-1832.

Xie, F., Lin, X., Wu, X., Xie, Z. (2008). Solid phase extraction of lead (II), copper (II), cadmium (II) and nickel (II) using gallic acid-modified silica gel prior to determination by flame atomic absorption spectrometry Talanta., 74, 836-843 